\title{
UJI EFIKASI EKSTRAK GULMA SIAM TERHADAP MORTALITAS HAMA PENCUCUK BUAH KAKAO (HELOPELTIS SPP.) DI LABORATORIUM
}

\author{
Yuyun Fitriana, Purnomo \& Agus M. Hariri \\ Bidang Proteksi Tanaman Jurusan Agroteknologi, Fakultas Pertanian, Universitas Lampung \\ E-mail: fitriana_yuyun@yahoo.co.id
}

\begin{abstract}
Efficasy test of siam weed extract on the mortality of cocoa mirid bugs (Helopeltis spp.) in the laboratory. This research was aimed to investigate the effect of siam weeds (C. odorata) extract on the mortality of Helopeltis spp., the effect of the addition of emulsifier on the toxicity of siam weed extract, and to find out a potential concentration of the siam weeds extract that can be used as bioinsecticide for Helopeltis spp. Six concentration levels of $C$. odorata were used as treatments: 0\% (control), $20 \%, 30 \%, 40 \%, 50 \%$ and $60 \%$ by adding $0.3 \%$ or no emulsifier. Data collected were mortality of nymphs and adults of Helopeltis spp. The results showed that the application of the siam weeds (C. odorata) extract was able to kill of nymph and adult of Helopeltis spp. The mortality of nymph ranged from $26.6 \%$ to $50.0 \%$ without emulsifier and $78.8 \%$ to $85.0 \%$ with emulsifier, and for adult range $15.00 \%-46.67 \%$ without emulsifier and $31.67 \%-71.67 \%$ with emulsifier for adult. The results confirm by adding emulsifier can enhance toxicity of siam weed extract to Helopeltis spp.. There was no significant effect of concentration level of siam weed on cocoa mirid mortality, therefore concentration level of $20 \%$ seems to be the potential concentration of siam weed extract that can be used as bioinsecticide of Helopeltis spp..
\end{abstract}

Key words: Chromolaena odorata, siam weed extract, Helopeltis spp., mortality

\begin{abstract}
ABSTRAK
Uji efikasi ekstrak gulma siam terhadap mortalitas hama pencucuk buah kakao (Helopeltis spp.) di Laboratorium. Penelitian ini bertujuan untuk mempelajari: pengaruh aplikasi ekstrak gulma siam terhadap tingkat mortalitas Helopeltis spp., pengaruh penambahan pengemulsi terhadap daya racun ekstrak gulma siam, dan untuk mendapatkan tingkat konsentrasi gulma siam yang berpotensi untuk digunakan sebagai bioinsektisida pengendali Helopeltis spp. Pengujian dilakukan pada 6 tingkat konsentrasi ekstrak gulma siam $0 \%$ (kontrol), 20\%, 30\%, 40\%, 50\% dan 60\% dengan dan tanpa penambahan 0,3\% pengemulsi. Data yang dikumpulkan dalam penelitian ini adalah tingkat mortalitas nimfa dan imago Helopeltis spp. setelah aplikasi. Hasil penelitian menunjukkan bahwa aplikasi ekstrak gulma siam mampu menyebabkan kematian nimfa dan imago Helopeltis spp. Tingkat mortalitas untuk nimfa berkisar dari 26,6\% hingga 50,0\% tanpa pengemulsi dan 78,8\% hingga 85,00\% dengan pengemulsi, dan untuk imago dari 15,0\% hingga 46,6\% tanpa pengemulsi dan 31,67\% hingga 71,67\% dengan pengemulsi. Hasil penelitian tersebut membuktikan bahwa penambahan pengemulsi dapat meningkatkan daya racun ekstrak gulma siam terhadap Helopeltis spp. Semua tingkat konsentrasi ekstrak gulma siam yang diujikan tidak mengakibatkan perbedaan mortalitas hama pencucuk buah kakao yang nyata, dengan demikian tingkat konsentrasi 20\% dapat dinyatakan sebagai konsentrasi yang berpotensi sebagai bioinsektisida terhadap Helopeltis spp..
\end{abstract}

Kata kunci: Chromolaena odorata, ekstrak gulma siam, Helopeltis spp., mortalitas

\section{PENDAHULUAN}

Hama pencucuk buah kakao Helopeltis spp. (Hemiptera: Miridae) merupakan salah satu hama penting tanaman kakao (Wardojo, 1992) dengan akibat kerugian yang ditimbulkan cukup besar, hingga mencapai 75\% (Atmadja, 2003). Sampai saat ini, pengendalian hama pencucuk buah kakao sangat sulit dilakukan. Pengendalian secara kultur teknis (seperti sarungisasi dan pembuangan buah yang terinfeksi) dan penggunaan varietas tahan ternyata kurang efisien dan atau tidak efektif untuk menekan kerugian yang disebabkan hama Helopeltis spp. (Atmadja, 2003). Selain itu penggunaan berbagai macam jenis insektisida yang dilaporkan efektif ternyata meninggalkan residu kimia yang berbahaya yang menimbulkan dampak negatif bagi pengguna, konsumen, dan lingkungan (Djojosumarto, 2000; Untung, 2001).

Hingga kini, upaya pencarian alternatif pengendalian yang lebih efektif, murah, aman, dan ramah lingkungan menjadi prioritas utama untuk menekan dampak negatif penggunaan pestisida kimia. Pemanfaatan pestisida nabati dengan memanfaatkan 
bahan-bahan tanaman yang mudah ditemukan di alam, mudah dibuat dan mudah diaplikasikan serta tidak meninggalkan residu kimia yang berbahaya menjadi salah satu pilihan.

Bahan tanaman yang digunakan sebagai pestisida nabati sebaiknya merupakan bahan tanaman yang tidak memiliki nilai ekonomi yang lebih tinggi apabila digunakan untuk keperluan yang lain (Prijono \& Triwidodo, 1993). Oleh sebab itu, usaha pemanfaatan bahan-bahan yang tidak mempunyai nilai ekonomis tetapi mempunyai potensi sebagai biopestisida (seperti gulma) saat ini perlu lebih dipelajari. Salah satu jenis gulma yang mempunyai potensi tersebut adalah gulma siam (Chromolaena odorata).

Gulma siam yang juga biasa dikenal dengan krinyuh atau gulma putihan merupakan jenis gulma yang sangat sulit untuk dikendalikan (Zachariades et al., 2009) dan menjadi permasalahan di berbagai lahan pertanian dan perkebunan (Muniappan \& Bamba, 1999; Zachariades et al., 2009). Bertolak belakang dengan peranannya sebagai gulma, ternyata gulma siam memiliki potensi untuk dimanfaatkan. Beberapa laporan menyebutkan bahwa ekstrak gulma siam dapat digunakan untuk mengendalikan beberapa jenis hama seperti nematoda (Meloidogyne incognita) (Thoden et al., 2007), Spodoptera litura (Utami, 2003) dan Spodoptera exigua (Haryati et al., 2004). Gulma siam juga dilaporkan bersifat toksik terhadap beberapa hama gudang seperti Sitophilus zeamais (Bouda et al., 2001), S. oryzae dan Tribolium castaneum (Owusu, 2001). Lebih jauh, Matur \& Davou (2007) melaporkan bahwa gulma siam juga bersifat toksik terhadap larva blackflies (Simulium sp). Namun demikian, sampai saat ini belum ada laporan tentang pengaruh ekstrak gulma siam terhadap Helopeltis spp., yang merupakan salah satu hama penting tanaman kakao.

\section{METODE PENELITIAN}

Tempat dan Waktu. Penelitian dilaksanakan di Laboratorium Hama Tumbuhan, Fakultas Pertanian Universitas Lampung, berlangsung dari bulan Oktober 2009 sampai bulan Februari 2010. Penelitian terdiri dari dua set percobaan yang disusun dalam Rancangan Acak Kelompok dengan tiga ulangan. Satu set percobaan menggunakan pengemulsi dan satu set percobaan lainnya tidak menggunakan pengemulsi. Penelitian dilaksanakan melalui beberapa tahapan yang meliputi penyiapan serangga uji, pembuatan ekstrak gulma siam, dan aplikasi ekstrak ke serangga uji.
Penyiapan Serangga Uji. Indukan serangga uji (Helopeltis spp.) yang digunakan berasal dari Balai Tanaman Obat dan Aromatika (Balittro) Bogor. Indukan tersebut kemudian dipelihara untuk mendapatkan Helopeltis spp. yang seragam untuk digunakan sebagai serangga uji. Metode pemeliharaan Helopeltis spp. mengacu pada metode yang dikembangkan oleh Balittro Bogor. Sebagai bahan pakan, buah mentimun dicuci dengan air mengalir sampai bersih kemudian dikeringanginkan. Sebanyak 10-20 indukan Helopeltis spp. (nimfa atau imago) dimasukkan ke dalam stoples plastik kemudian diberi pakan (mentimun) dan ditutup dengan kain sipon. Stoples kemudian diberi label yang berisi informasi nama/spesies serangga yang dipelihara, tanggal penetasan dan peneluran. Nimfa yang digunakan sebagai serangga uji merupakan nimfa instar 3 dan 4, sedangkan imago yang digunakan merupakan imago yang baru berubah dari nimfa instar 5 .

Pembuatan Ekstrak Gulma Siam. Gulma siam ditimbang sebanyak $100 \mathrm{~g}$ kemudian dicuci dengan air mengalir dan ditiriskan. Setelah itu gulma siam dan aquades $100 \mathrm{ml}$ diblender sampai halus kemudian disaring menggunakan kain sipon. Ekstrak gulma siam ini merupakan ekstrak gulma siam dengan konsentrasi $100 \%$, yang merupakan larutan stok.

Perlakuan dalam percobaan ini terdiri dari enam tingkat konsentrasi ekstrak gulma siam, yaitu $0 \%$ (sebagai kontrol), 20\%, 30\%, 40\%, 50\% dan 60\% tanpa dan dengan penambahan $0,3 \%$ pengemulsi berupa deterjen. Tingkat konsentrasi gulma siam yang digunakan dipilih dengan mempertimbangkan bahwa tingkat konsentrasi tersebut merupakan tingkat konsentrasi yang memungkinkan untuk dibuat oleh petani di lapangan. Penggunaan deterjen sebagai pengemulsi didasarkan pada kenyataan bahwa pada umumnya petani akan menambahkan deterjen sebagai pengemulsi pada saat mengaplikasikan pestisida nabati. Secara keseluruhan setiap set percobaan yang terdiri dari enam perlakuan dan tiga ulangan sehingga terdapat 18 satuan percobaan. Setiap satuan percobaan terdiri atas 20 ekor serangga Helopeltis spp. baik nimfa ataupun imago.

Ekstrak gulma siam yang sudah disaring, kemudian diencerkan sesuai dengan tingkat konsentrasi yang diuji. Misalnya untuk konsentrasi $20 \%$, ekstrak yang dimasukkan ke dalam gelas ukur sebanyak $20 \mathrm{ml}$, kemudian ditambahkan pengemulsi deterjen $0,3 \mathrm{~g}$ dan aquades hingga mencapai $100 \mathrm{ml}$.

Cara Aplikasi. Larutan ekstrak gulma siam (baik dengan maupun tanpa pengemulsi deterjen ) dimasukkan 
ke dalam hand sprayer dan siap untuk diaplikasikan. Dua puluh ekor serangga Helopeltis spp. diaplikasi di dalam wadah aplikasi. Setelah diaplikasi, serangga dipindahkan menggunakan kuas kecil ke dalam stoples plastik yang ditutup dengan kain sipon sebagai tempat pemeliharaan. Serangga diberi pakan mentimun (1 buah mentimun untuk 1 stoples) dan diberi label sesuai perlakuan.

Pengamatan dan Pengumpulan Data. Pengamatan dilakukan setiap hari hingga 3 hari setelah aplikasi terhadap jumlah nimfa ataupun imago yang mati. Tingkat mortalitas nimfa dan imago Helopeltis spp. dihitung dengan menggunakan rumus :

$$
\operatorname{Tm}=\frac{\mathrm{n}}{\mathrm{N}} \times 100 \%
$$

dengan,

Tm $=$ tingkat mortalitas $(\%)$,

$\mathrm{n}=$ jumlah nimfa atau imago yang mati, dan

$\mathrm{N}=$ jumlah nimfa atau imago total.

Analisis Data. Data persentase mortalitas Helopeltis sp. yang diperoleh kemudian dianalisis dengan sidik ragam dan dilanjutkan dengan uji BNT pada taraf 5\%.

\section{HASIL DAN PEMBAHASAN}

Mortalitas Nimfa Helopeltis spp. Hasil percobaan menunjukkan bahwa 3 hari setelah aplikasi (hsa), aplikasi ekstrak gulma siam dengan penambahan pengemulsi secara umum menghasilkan tingkat mortalitas nimfa Helopeltis spp. yang lebih tinggi daripada aplikasi ekstrak gulma siam tanpa penambahan pengemulsi (Tabel 1). Untuk aplikasi tanpa penambahan pengemulsi, tingkat konsentrasi $60 \%$ menghasilkan tingkat mortalitas yang paling tinggi dibandingkan perlakukan lainnya dan berbeda nyata dengan kontrol. Sedangkan aplikasi dengan penambahan pengemulsi menunjukkan bahwa semua tingkat konsentrasi menghasilkan tingkat mortalitas yang secara nyata lebih baik daripada kontrol (Tabel 1). Meskipun demikian, sesungguhnya tidak terdapat perbedaan yang signifikan antarperlakuan beda konsentrasi pada percobaan tersebut. Dengan demikian, penggunaan konsentrasi 20\% dianggap lebih efisien dibandingkan dengan konsentrasi yang lebih tinggi.

Mortalitas Imago Helopeltis spp. Seperti halnya pada nimfa, aplikasi ekstrak gulma siam pada imago juga dilakukan dengan dan tanpa penambahan pengemulsi. Pada 3 hari setelah aplikasi (hsa), secara umum aplikasi ekstrak gulma siam dengan penambahan pengemulsi menghasilkan tingkat mortalitas imago Helopeltis spp. yang lebih tinggi dibandingkan dengan aplikasi ekstrak gulma siam tanpa penambahan pengemulsi. Tingkat mortalitas tertinggi, baik pada aplikasi dengan dan tanpa penambahan pengemulsi, dihasilkan oleh aplikasi ekstrak gulma siam pada tingkat konsentrasi $20 \%$ yaitu sebesar 46,67\% (tanpa penambahan penemulsi) dan $71,67 \%$ (dengan penambahan pengemulsi). Pada perlakuan tanpa penambahan pengemulsi, tingkat mortalitas yang dihasilkan oleh konsentrasi 20\% tidak menunjukkan perbedaan yang nyata dibandingkan dengan kontrol. Namun dengan menambahkan pengemulsi, tingkat mortalitas yang dihasilkan oleh tingkat konsentrasi $20 \%$ secara nyata lebih baik dibandingkan dengan kontrol (Tabel 2).

Penambahan pengemulsi pada aplikasi ekstrak gulma siam ternyata secara umum mampu meningkatkan tingkat mortalitas nimfa dan imago Helopeltis spp. Aplikasi pada semua tingkat konsentrasi menghasilkan mortalitas yang lebih tinggi daripada tanpa penambahan pengemulsi (Tabel 1 dan 2). Hasil ini

Tabel 1. Tingkat mortalitas nimfa Helopeltis spp. pada 3 hari setelah aplikasi ekstrak gulma siam pada berbagai tingkat konsentrasi

\begin{tabular}{ccc}
\hline \multirow{2}{*}{ Perlakuan } & \multicolumn{2}{c}{ Tingkat mortalitas imago Helopeltis spp. $(\%)$} \\
\cline { 2 - 3 } & Tanpa pengemulsi & Dengan peng emulsi \\
\hline $20 \%$ & $46,6 \mathrm{a}$ & $71,6 \mathrm{a}$ \\
$30 \%$ & $28,3 \mathrm{ab}$ & $40,0 \mathrm{ab}$ \\
$40 \%$ & $23,3 \mathrm{ab}$ & $31,6 \mathrm{~b}$ \\
$50 \%$ & $26,6 \mathrm{ab}$ & $36,6 \mathrm{ab}$ \\
$60 \%$ & $15,0 \mathrm{~b}$ & $43,3 \mathrm{ab}$ \\
$0 \%$ (Kontrol) & $30,0 \mathrm{ab}$ & $18,3 \mathrm{~b}$ \\
\hline
\end{tabular}

Nilai dalam satu kolom yang diikuti huruf yang sama menunjukkan tidak berbeda nyata pada uji BNT ( $\mathrm{p}>0,05)$. 
menunjukkan bahwa penambahan pengemulsi ternyata dapat meningkatkan daya racun ekstrak gulma siam untuk menyebabkan kematian nimfa dan imago Helopeltis spp.

Untuk melihat lebih jelas pengaruh penambahan pengemulsi, dirata-ratakanlah semua nilai tanpa memperhatikan tingkat konsentrasi. Uji statistik menunjukkan bahwa penambahan pengemulsi mempunyai pengaruh yang secara nyata lebih baik terhadap tingkat mortalitas nimfa Helopeltis spp. namun tidak bagi imago (Gambar 1). Kondisi ini menunjukkan bahwa konsentrasi bahan aktif yang terkandung di dalam gulma siam sebelum dan sesudah ditambahkannya pengemulsi (deterjen) tidak terlalu berpengaruh terhadap tingkat mortalitas imago. Kemampuan beradaptasi imago terhadap tekanan lingkungan yang lebih baik daripada nimfa diduga menjadi salah satu faktor penyebabnya. Kemampuan beradaptasi imago yang lebih baik ini juga ditunjukkan dengan tingkat mortalitas imago yang lebih rendah daripada nimfa setelah diaplikasikan ekstrak gulma siam pada semua tingkat konsentrasi.

Pada umumnya, senyawa kimia yang bersifat toksik terhadap serangga berupa minyak atau lemak, alkaloids, terpenoid, senyawa fenol atau senyawa benzoat (Bakkali et al., 2008). Senyawa-senyawa tersebut bersifat nonpolar dan tidak bisa terlarut

Tabel2. Tingkat mortalitas imago Helopeltis spp. pada 3 hari setelah aplikasi ekstrak gulma siam pada berbagai tingkat konsentrasi

\begin{tabular}{ccc}
\hline \multirow{2}{*}{ Perlakuan } & \multicolumn{2}{c}{ Tingkat mortalitas nimfa Helopeltis spp. (\%) } \\
\cline { 2 - 3 } & Tanpa peng emulsi & Dengan peng emulsi \\
\hline $20 \%$ & $46,6 \mathrm{a}$ & $71,6 \mathrm{a}$ \\
$30 \%$ & $28,3 \mathrm{ab}$ & $40,0 \mathrm{ab}$ \\
$40 \%$ & $23,3 \mathrm{ab}$ & $31,6 \mathrm{~b}$ \\
$50 \%$ & $26,6 \mathrm{ab}$ & $36,6 \mathrm{ab}$ \\
$60 \%$ & $15,0 \mathrm{~b}$ & $43,3 \mathrm{ab}$ \\
$0 \%$ (Kontrol) & $30,0 \mathrm{ab}$ & $18,3 \mathrm{~b}$ \\
\hline
\end{tabular}

Nilai dalam satu kolom yang diikuti huruf yang sama menunjukkan tidak berbeda nyata pada uji BNT ( $\mathrm{p}>0,05)$.

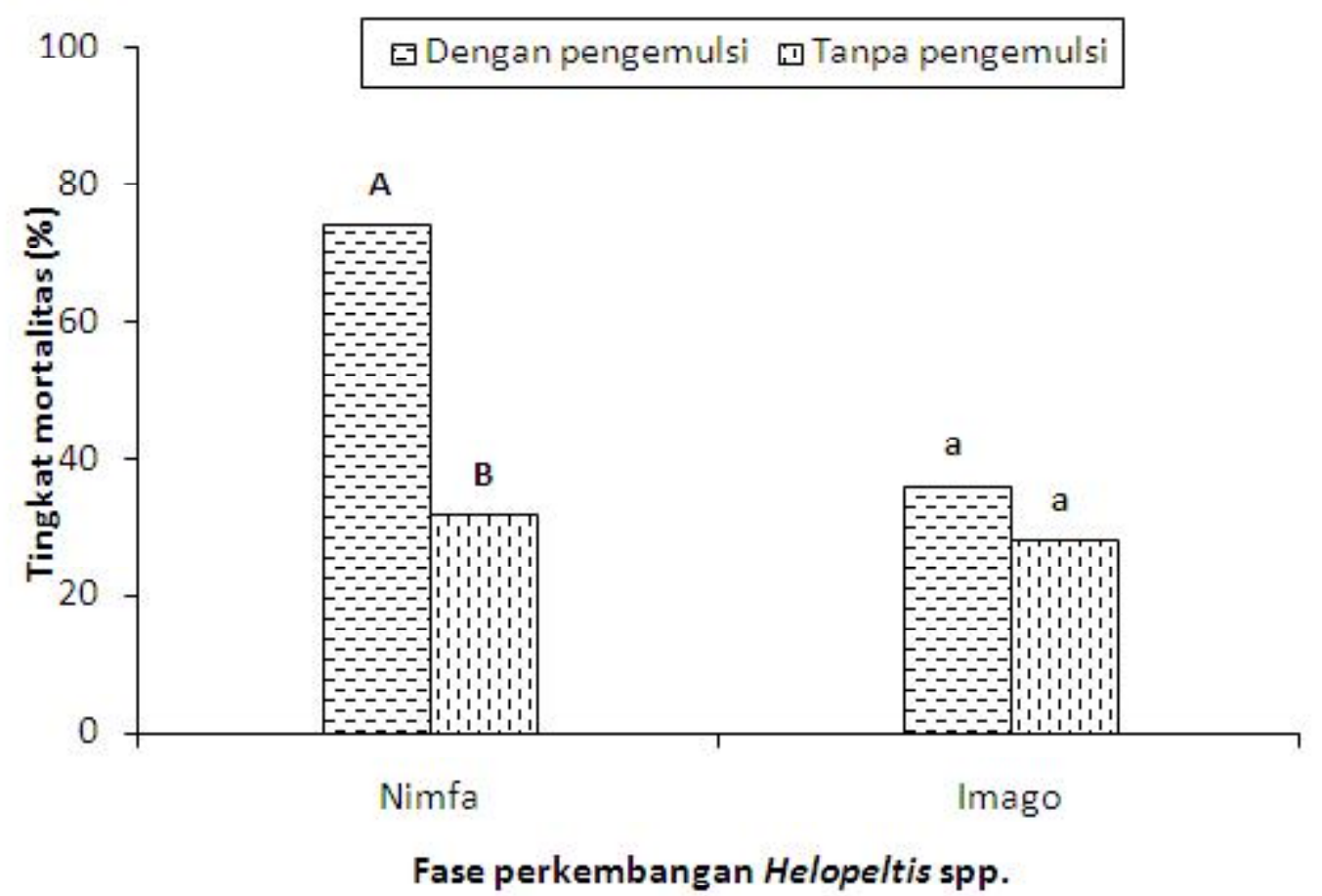

Gambar 1. Pengaruh penambahan pengemulsi terhadap mortalitas nimfa dan imago Helopeltis spp. Huruf (Nilai yang diikuti denan huruf yang samamenunjukkan tidak berbeda nyata pada uji BNT (p>0,05). 
sempurna di dalam air, oleh karena itu, untuk dapat melarutkannya diperlukan adanya tambahan pengemulsi (Bi et al., 2010 dan Heryanto et al., 2007).

Deterjen telah banyak dilaporkan dapat berfungsi sebagai pengemulsi (Shete et al., 2006; Chen et al., 2010) dan hingga saat ini telah secara luas digunakan oleh petani untuk diaplikasikan bersama-sama dengan pestisida nabati (Djunaedy, 2009). Penambahan deterjen sebagai pengemulsi akan dapat meningkatkan keterlarutan kandungan bahan aktif di dalam pestisida nabati sehingga akan dapat meningkatkan tingkat konsentrasi bahan aktif yang terkandung di suspensi ekstrak gulma siam. Penambahan deterjen sebagai pengemulsi pada waktu aplikasi ekstrak gulma siam sangat dianjurkan untuk meningkatkan daya racun ekstrak gulma siam terhadap Helopeltis spp. di lapangan.

Penghitungan nilai rata-rata mortalitas tanpa memperhatikan pengaruh penambahan pengemulsi menunjukkan bahwa secara umum, semua tingkat konsentrasi ekstrak gulma siam menghasilkan tingkat mortalitas nimfa dan imago Helopeltis spp. yang lebih besar daripada kontrol. Tingkat mortalitas nimfa dan imago Helopeltis spp. tertinggi dicapai oleh aplikasi ekstrak gulma siam pada tingkat konsentrasi $20 \%$ yaitu sebesar 55,8\% (nimfa) dan 58,3\% (imago). Uji statistik menunjukkan bahwa tingkat konsentrasi $20 \%$ menghasilkan tingkat mortalitas yang secara nyata lebih baik daripada kontrol (Tabel 3). Hasil ini menunjukkan bahwa tingkat konsentrasi 20\% merupakan tingkat konsentrasi yang berpotensi untuk dapat diaplikasikan dalam mengendalikan Helopeltis spp. di lapangan.

Kemampuan ekstrak gulma siam untuk menyebabkan kematian terhadap beberapa serangga diduga karena gulma ini mengandung beberapa senyawa kimia yang bersifat toksik terhadap serangga. Owolabi et al. (2010) menyebutkan bahwa gulma siam mengandung beberapa senyawa kimia utama antara lain $\alpha$-pinene $(42,2 \%), \beta$-pinene $(10,6 \%)$, germacrene D $(9,7 \%)$, $\beta$-copaen-4 $\alpha$-ol $(9,4 \%)$, (E)-caryophyllene
$(5,4 \%)$, dan geijerene/pregeijerene $(7,5 \%)$. Gulma siam juga dilaporkan mengandung Pyrrolizidine alkaloids (Thoden et al., 2007) yang merupakan senyawa sekunder yang diproduksi oleh tanaman dan berfungsi sebagai senyawa pertahanan tanaman terhadap herbivora (Hartmann, 2004; Rasmann \& Agrawal, 2009). pyrrolizidine alkaloids (PAs) dilaporkan dapat mengakibatkan mutagenesis pada serangga (Hartmann, 2004) seperti Drosophila melanogaster (Frei et al., 1992) dan juga telah dilaporkan bersifat toksik pada nematoda (Thoden et al., 2007) dan Philosamia ricini (Narberhaus et al., 2005).

\section{SIMPULAN}

Dari hasil penelitian dapat disimpulkan bahwa aplikasi ekstrak gulma siam mempunyai kemampuan untuk menyebabkan kematian nimfa dan imago Helopeltis spp. Penambahan pengemulsi ternyata dapat meningkatkan daya racun ekstrak gulma siam terhadap Helopeltis spp. Tingkat konsentrasi 20\% merupakan tingkat konsentrasi yang berpotensi digunakan untuk dapat mengendalikan Helopeltis spp..

\section{SANWACANA}

Penelitian ini dibiayai oleh DIPA APBN Universitas Lampung Tahun 2010, sesuai dengan Surat Perjanjian Kontrak Nomor: 2644 A/H26/KU/2010 Tanggal 14 Juni 2010. Ucapan terima kasih kami ucapkan kepada Juanda Barus, S.P. yang telah terlibat dalam penelitian ini sejak awal hingga selesai. Kami juga mengucapkan terima kasih kepada Giwantoro dan Widyaningrum atas bantuan teknis yang telah diberikan.

Tabel 3. Pengaruh tingkat konsentrasi ekstrak gulma siam terhadap tingkat mortalitas nimfa dan imago Helopeltis spp.

\begin{tabular}{ccl}
\hline Perlakuan & Nimfa & Imago \\
\hline $20 \%$ & $55,83 \mathrm{a}$ & $58,33 \mathrm{a}$ \\
$30 \%$ & $50,83 \mathrm{ab}$ & $33,33 \mathrm{ab}$ \\
$40 \%$ & $60,83 \mathrm{a}$ & $25,00 \mathrm{~b}$ \\
$50 \%$ & $55,00 \mathrm{ab}$ & $28,33 \mathrm{ab}$ \\
$60 \%$ & $65,00 \mathrm{a}$ & $26,67 \mathrm{ab}$ \\
$0 \%$ (Kontrol) & $30,83 \mathrm{~b}$ & $20,83 \mathrm{~b}$ \\
\hline
\end{tabular}

Nilai dalam satu kolom yang diikuti huruf yang sama menunjukkan tidak berbeda nyata pada uji BNT ( $>0,05)$. 


\section{DAFTAR PUSTAKA}

Atmadja WR. 2003. Status Helopeltis antonii sebagai hama pada beberapa tanaman perkebunan dan pengendaliannya. J. Litbang Pertanian 22(2): 57-62.

.Bakkali F, Averbeck S, Averbeck D\& Idaomar M. 2008. Biological effects of essential oils - A review. Food and Chemical Toxicology 46: 446475.

Bi P, Dong H \& Dong J. 2010. The recent progress of solvent sublation. J. of Chromatography A. 1217 :2716-2725.

Bouda H, Tapondjou LA, Fontem DA \& Gumedzoe MYD. 2001. Effect of essential oils from leaves of Ageratum conyzoides, Lantana camara and Chromolaena odorata on the mortality of Sitophilus zeamais (Coleoptera, Curculionidae). J. of Stored Products Research 37 :103-109.

Chen YF, Yang CH, Chang MS, Ciou YP \& Huang YP. 2010. Foam Properties and Detergent Abilities of the Saponins from Camellia oleifera. Int. J. Mol. Sci. 11:4417-4425.

Djojosumarto P. 2000. Teknik Aplikasi Pestisida Pertanian. Kanisius. Yogyakarta.

Djunaedy, A. 2009. Biopestisida sebagai pengendali organisme pengganggu tanaman (OPT) yang ramah lingkungan. Embryo 6(1): 88-95

Frei H, Luthy J, Brauchli J, Zweifel U, Wurgler FE \& Schlatter C. 1992. Structure/Activity Relationships of the Genotoxic Potencies of Sixteen Pyrrolizidine Alkaloids Assayed for the Induction of Somatic Mutation and Recombination in Wing Cells of Drosophila melanogaster. Chem.-Biol. Interactions 83:1-22.

Haryati S, Hidayah N, Haryono K, Suharjo R, Soffan A \& Swari FD. 2004. Pemanfaatan Ekstrak Gulma Siam (Chromolaena odorata) untuk mengendalikan Spodoptera exigua pada Pertanaman Bawang merah di Kretek. Bantul. Laporan Akhir Program Kreativitas Mahasiswa. Universitas Gadjah Mada Yogyakarta (tidak dipublikasikan).

Hartmann T. 2004. Plant-derived secondary metabolites as defensive chemicals in herbivorous insects: a case study in chemical ecology. Planta 219:1- 4.
Heryanto R, Hasan M, Abdullah EC \& Kumoro AC. 2007. Solubility of Stearic Acid in Various Organic Solvents and Its Prediction using Non-ideal Solution Models. Science Asia 33:469-472.

Matur BM \& Davou BJ. 2007. Comparative Larvicidal Property of Leaf Extract of Chromolaena odorata L (Composidae) and Chlopyrifos (Organophosphorus Compound) on Simulium Larvae. Biomedical and Environmental Sciences 20:313-316.

Muniappan R \& Bamba J. 1999. Biological Control of Chromolaena odorata: Successes and Failures. Proceedings of the X International Symposium on Biological Control of Weeds 4-14 July 1999, Montana State University, Bozeman, Montana, USA

Narberhaus I, Zintgraf V \& Dobler S. 2005. Pyrrolizidine alkaloids on three trophic levels evidence for toxic and deterrent effects on phytophages and predators. Chemoecology 15 : 121-125.

Owolabi MS, Ogundajo A, Yusuf KO, Lajide L, Villanueva HE, Tuten JA \& Setzer WN. 2010. Chemical Composition and Bioactivity of the Essential Oil of Chromolaena odorata from Nigeria. Rec. Nat. Prod. 4(1):72-78.

Owusu EO. 2001. Effect of some Ghanaian plant components on control of two stored-product insect pests of cereals. J. of Stored Products Research 37:85-91.

Prijono D \& Triwidodo H. 1993. Pemanfaatan Insektisida Nabati di Tingkat Petani. Prosiding Seminar hasil Penelitian dalam Rangka Pemanfaatan Pestisida Nabati. Balai Penelitian tanaman Rempah dan Obat. Bogor.1-2 Desember 1993.

Rasmann S \& Agrawal AA. 2009. Plant defense against herbivory: progress in identifying synergism, redundancy, and antagonism between resistance traits. Current Opinion in Plant Biology 12: 473 -478 .

Shete AM, Wadhawa G, Banat IM, Copade BA. 2006. Mapping of patents on bioemulsifier and biosurfactant : a review. J. Sci. Ind. Res. 65:91115 
Thoden TC, Bppre M \& Hallmann J. 2007. Pyrrolizidine Alkaloid of Chromolaena odorata act as nematicidal agents and reduce infection of lettuce roots by Meloidogyne incognita. Nematology 9(3):343-349.

Untung K. 2001. Pengantar Pengelolaan Hama Terpadu. Gadjah Mada University Press. Yogyakarta.

Utami NRE. 2003. Uji Toksisitas Ekstrak Daun dan Batang Chromolaena odorata terhadap Spodoptera litura. Skripsi. Fakultas Pertanian UGM. Yogyakarta.
Wardojo S. 1992. Major Pest and Diseases of Cocoa in Indonesia. Pp. 63 - 67 In: Keane PJ \& Putter CAJ (eds.). Cocoa Pest and Diseases Management in Southeast Asia and Australia. Food and Agriculture Organization of the United Nations..

Zachariades, Day CM, Muniappan R \& Reddy GVP. 2009. Chromolaena odorata (L.) King and Robinson (Asteraceae).Pp:130 - 162 In: Muniappan, R, Reddy GVP \& Raman. A Biological Control of Tropical Weeds using Arthropods. Cambridge University Press. Cambridge. 